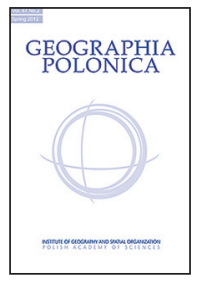 \\ INSTITUTE OF GEOGRAPHY AND SPATIAL ORGANIZATION \\ POLISH ACADEMY OF SCIENCES \\ www.igipz.pan.pl \\ www.geographiapolonica.pl
}

\title{
A SYNTHETIC INDEX OF THE SPATIO-TEMPORAL ACCESSIBILITY OF COMMUNES IN POLAND
}

\section{Przemysław Śleszyński}

Institute of Geography and Spatial Organization

Polish Academy of Sciences

Twarda 51/55, 00-818 Warsaw: Poland

e-mail: psleszyn@twarda.pan.pl

\begin{abstract}
This study presents mapping of Poland on the basis of a synthetic index of spatial accessibility to administrative and settlement centres of three categories, i.e. voivodeship (capitals of the country's 18 province-regions), sub-regional and poviat (i.e. the capitals of county-level administrative units). Temporal accessibility by means of private car was referred to, on the basis of the author's own traffic speed model, while the starting point for the map work was isochrone analysis carried out for the centres of the three aforementioned categories. Results were then summed using an original algorithm that weights different categories of accessibility to the urban centres in relation to the latter's demographic potential.
\end{abstract}

\section{Key words}

temporal accessibility $\bullet$ spatial accessibility $\bullet$ transport accessibility $\bullet$ accessibility indices $\bullet$ proximity $\bullet$ peripherality $\bullet$ settlement hierarchy $\bullet$ Poland

\section{Introduction: formulation of research problem}

Spatial accessibility can be considered in various ways, depending on the concepts and definitions adopted. The relevant literature here is very extensive, and has been reviewed and presented in terms of prospects for further development in such works as Geurs and Ritsema van Eck (2001), Geurs and van Wee
(2013), and the study by Litman (2016) subject to continual updating. Recent Polish input in this area has in turn been epitomised by Komornicki et al. (2010) and Śleszyński (2014a).

Time is widely accepted as the universal measure of spatial access, given the way it reflects a fundamental principle of human conduct - a desire to maximise contacts while at the same time minimising the activity (i.e. effort) needing to be put in to maintain those 
said contacts (Karlqvist 1975). The universality of time reflects its prevalence and comparability everywhere, and its absolute nature (in the sense that all events take part within the same timeframe).

The measuring of temporal accessibility involves a wide variety of methods, above all associated with journeys by means of transport that allow given distances to be covered. Transport accessibility is here determined by the way in which space has been utilised and managed, most especially as regards the nature of the transport network that allows movement to take place in different conditions, as well as the organisation of transport systems (above all public transport).

For the above reasons, it is very typical for work on accessibility to resort to isochrone analysis. However, basic limitations here reflect the way in which the cartographic method only allows for accessibility to be presented in relation to one point, or a limited number of points (even if many). This of course relates to just some of the possible types of accessibility, and to depict that accessibility by means of the isochrone method many maps have to be made with the isochrones transferred to and marked on them. A question therefore arises as to how a synthetic means by which to present temporal accessibility in all its aspects effectively might be arrived at, with this also proving to be in any way comparable.

To come up with a more transparent formulation of the issue, the following situation needs to be imagined. From point $A$, it is possible to achieve the independent determination of isochrones to two points B and C, whose significance is nevertheless different overall, from the point of view of the traveller, leaving simple addition of the two travel times as an inadequate solution. A question arising from that concerns the possibility for some kind of presentation of synthetic accessibility that would take account of the different features of the aforesaid points B and C. Equally, a full accessibility matrix in the meaning of the gravitation and potential model is not what would be involved here, but rather a more simple modelling of the time that would not nevertheless be the product of that time and the masses of points $B$ and $C$.

The work described in this paper has thus had as its aim the presentation and propounding of a method that would permit the construction of synthetic isochrone analysis-based maps of temporal accessibility from a given point to many other places. The core issue to be dealt with here is thus the discovery of a universal point of reference that would make the aforementioned 'weighting' of degrees of temporal separation possible.

\section{Methodology}

The solution to the problem detailed above entails a 'weighting' of temporal distance or degree of separation in respect of different categories of point (in this case towns and cities), using a common measure. It is here proposed that the measure should be shared in the overall set. Thus, given the situation presented in the introduction, the achievement of a synthetic index depends on journey times from point $A$ being weighted by reference to the shares these account for within the whole set of points A and B. Number of people, number of enterprises or any other comparable index might be used here, but this particular analysis makes use of the populations of towns and cities.

Drawing on many other accessibility studies (Śleszyński 2014a, b, d), three categories of urban centre in Poland are identified ${ }^{1}$ :

a) the so-called voivodeship cities (i.e. the capitals of the 16 province-regions, or voivodeships, into which Poland has been divided since 1 January 1999);

b) the sub-regional towns or cities (i.e. remaining 51 urban localities enjoying poviat (county-level) rights or else being at one time capitals of the (49) voivodeships

1 Certain analyses also offer individual treatment to Warsaw, as the one and only 'capital-city centre', as followed by a category of voivodeship centres taken to represent the core of the regional centres category, into which are included large cities not enjoying the status of capitals of province-regions, i.e. Bielsko-Biała, Częstochowa, Radom and Rybnik. 
existing under the previous administrative division of Poland, i.e. Sieradz, Piła and Ciechanów);

c) the poviat towns (i.e. the remaining 253 towns serving the function of capitals of the Polish units of administration at the county level known as poviats).

The analysis related to access by individual means of transport, on the basis of an assumption that the private car is a relatively universal good that is i.a. closely related to the structure of passenger carriage work in Poland. This is obviously a simplification to a certain degree, and one that does provide for some distortion of real accessibility associated with economic costs or access in the case of some specific excluded groups in society, or at least groups limited in the use they can make of cars, given their status as old, disabled, young, etc. However, an advantage of the method is in turn the chance it provides for dedicated and relevant traffic-speed models and databases to be used, on the basis of comparable results.

Calculations thus drew on a model of speeds achieved by traffic comprising individual passenger cars, as devised for a vectoral road network base made up of some 500,000 sections or stretches of road - and hence on average some 200 for each of the 2,479 areas known as communes (or gminas) into which Poland is divided at the localauthority level. Such a level of detail ensured a relatively effective reflecting and modelling of the degree of temporal separation of different communes from different centres, most especially those at poviat level. The traffic speed model was developed at the Institute of Geography and Spatial Organization of the Polish Academy of Sciences (Śleszyński 2015) and has for example gained application in analyses meeting the needs of Poland's latest national concept regarding spatial planning and physical development, i.e. National Spatial Development Plan 2030 (Koncepcja Przestrzennego Zagospodarowania Kraju 2030).

The model i.a. accounts for limitations arising out of Poland's Highway Code, the technical and operating parameters of different roads, density of population and morphometric diversity relating to relief (on the basis of an original index of standard deviations for altitudes (Śleszyński 2012). On the other hand, a key limitation of this approach was an inability to take account of the parameter of traffic intensity. All of the elements referred to are obviously capable of influencing actual travel speeds achieved, and hence estimated real accessibility of localities in temporal and spatial terms.

The detailed means of proceeding was as follows. An isochrone map presenting 1- or 5-minute intervals was first devised, in order to depict journey times to the nearest centre in a given category (Figs. 1-3). The mean degree of temporal separation of a given commune from the nearest centre of a town or city in a given category was then calculated, with central points being identified in relation to the concentration of city-centre functions. Since a given commune was embraced by a large number of isochrones, the calculations of travel times were weighted in line with the areas of these located within a given isochrone. However, accessibility is then capable of being approximated in such a way that the journey time may reflect traffic-speed conditions for as large a number of people as possible, rather than area (i.e. with a population-density weighting based around Census units; Śleszyński 2014c).

The Index of accessibility as calculated ultimately was thus a component of the degree of spatial separation pertaining between a given commune and urban settlement centres at the three aforementioned (voivodeship, sub-regional and local) levels. In this a weighting arising out of the demographic potentials of these different centres in Poland was applied. The final model for the $W$, index was thus expressed by an equation in the form:

$$
W_{1}=0,37 t_{v}+0,25 t_{s}+0,38 t_{p^{\prime}}
$$

where:

$t_{v}$ - the averaged journey time for a given commune to the centre of its voivodeship city,

$t_{s}$ - the averaged journey time from a given commune to the centre of its sub-regional centre,

$t_{p}$ - the averaged journey time from a given commune to the centre of its poviat town. 
Solutions of this kind gained their first application in the work by Mazur et al. (2015), with the results of the calculations serving among the main indicators used in delimiting rural functional areas which have in turn gained use in the quantification of approaches to the localisation of developments.

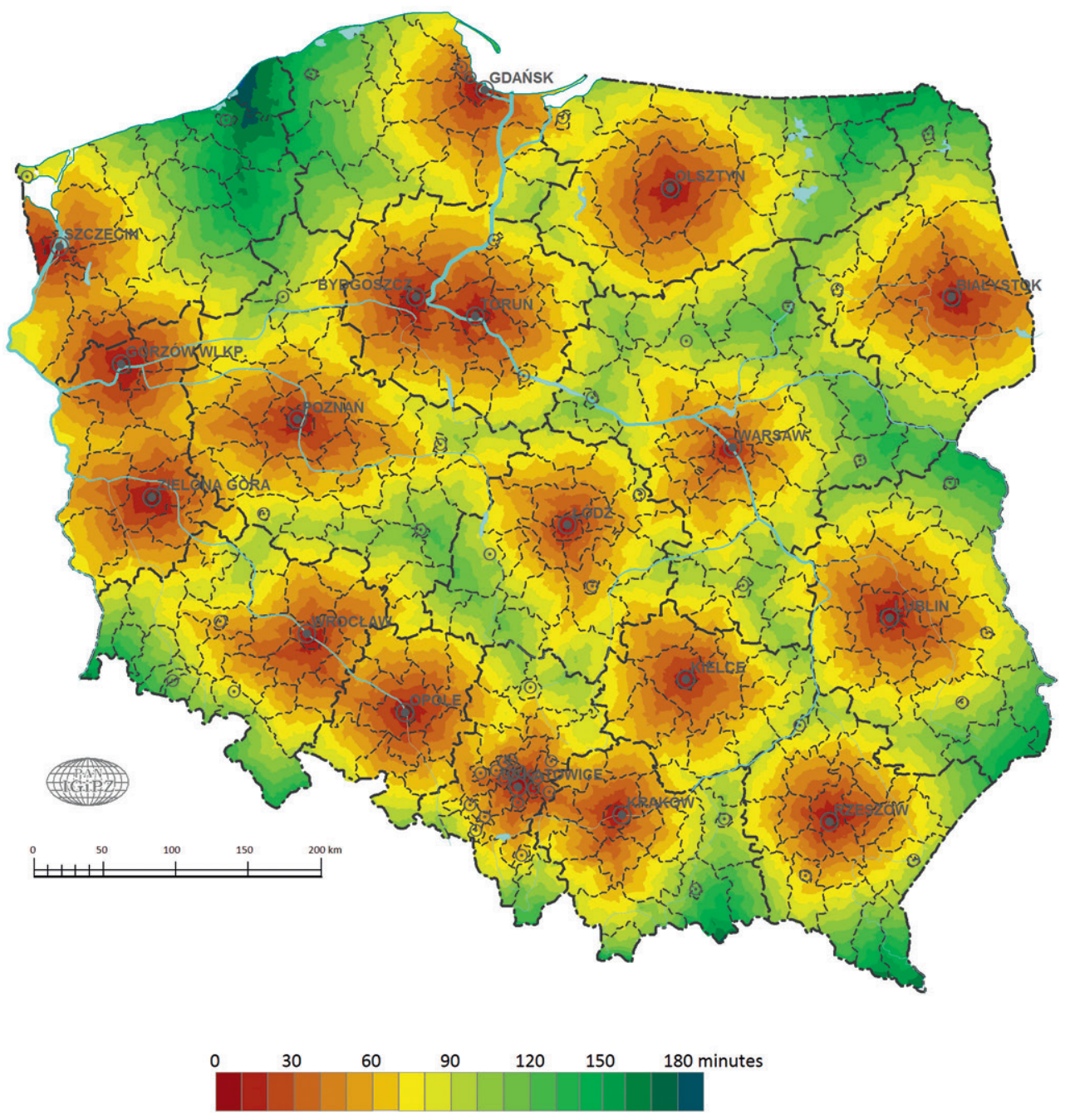

Figure 1. Isochrones for journey times by private car to the centres of voivodship cities, as of 2012 


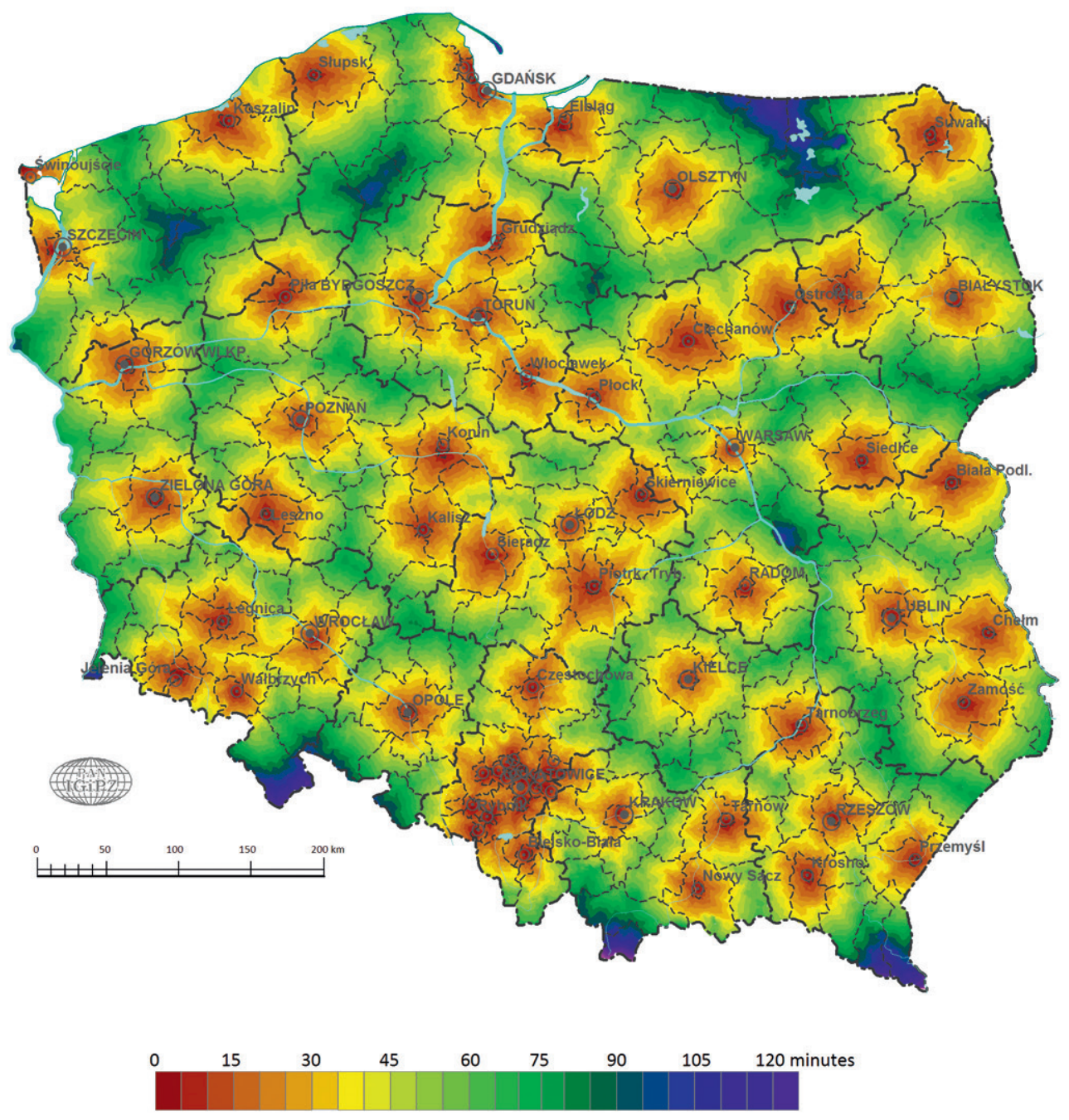

Figure 2. Isochrones for journey times by private car to the centres of sub-regional cities, as of 2012 


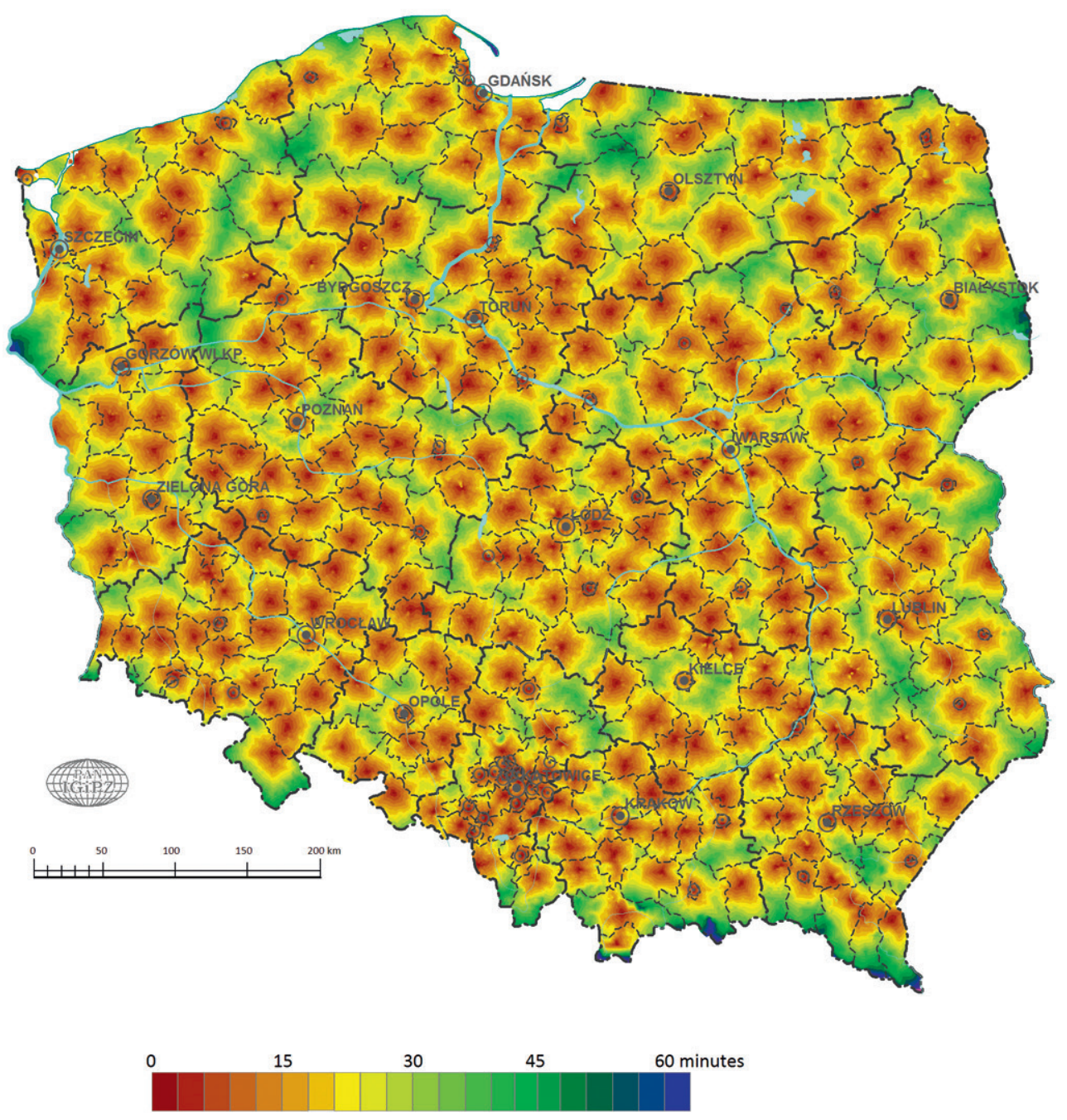

Figure 3. Isochrones for journey times by private car to the centres of poviat centers, as of 2012 


\section{Results}

The map in the attached insert presents the differentiation obtained for the synthetic index of temporal accessibility. It comprises the sum of the journey times from a given commune to the central parts of its nearest centres on the voivodship city, sub-regional centre and poviat town or city levels.

For convenience (and greater transparency) of analysis, it is worth approaching the assessment of accessibility by reference to the concepts of proximity and peripherality. The lower the value of the index, the greater the proximity, while conversely a higher value for the index denotes peripherality as encapsulated synthetically. Given that the voivodeship cities have rather major (37\%) weight attached to them, peripheral areas are first and foremost visible where distances (or levels of separation) from these centres are concerned. The lower-order centres go some way to evening out differences in accessibility, though in places where the degree of separation from the capitals of the province-regions is particularly marked, the index of temporal peripherality anyway continues to assume high values. On the other hand, there is a favourable influence where a place is not very much separated (distant) from a voivodeship centre, and there is also a town or city enjoying poviat (county-level) rights, as is the case in the Suwałki Lakeland area, for example, as well as around Radom and Tarnów.

Overall, values for the index of accessibility (also therefore of proximity and peripherality) for all the local-authority areas (communes) into which Poland is divided range between less than 10 and almost 100 conventional minutes. These are nevertheless extreme values, representing on the one hand the urban communes that actually are poviat capitals, or else rural communes and small towns located far from the main centres of socio-economic life. In fact, a majority of communes are characterised by values of the index in the range 30-60 conventional minutes.

Areas characterised by particularly high values for the index of peripherality are usually located in border areas of the country as a whole, or its component voivodeships. That said, it is possible to identify the several contiguous, larger aggregations of communes numbered on the map (see also Tab. 1).

Table 1. Basic information on peripheral areas distinguished (estimate data, on account of approximated assignment of communes)

\begin{tabular}{|c|c|c|c|c|c|c|c|}
\hline \multirow{2}{*}{$\begin{array}{l}\text { Peripheral areas } \\
\text { (original names) }\end{array}$} & \multirow{2}{*}{$\begin{array}{l}\text { Number } \\
\text { of com- } \\
\text { munes }\end{array}$} & \multirow{2}{*}{$\begin{array}{l}\text { Area } \\
\left(\mathrm{km}^{2}\right)\end{array}$} & \multirow{2}{*}{$\begin{array}{l}\text { Number of } \\
\text { population } \\
\text { (thous) }\end{array}$} & \multicolumn{3}{|c|}{$\begin{array}{l}\text { Average time accessibility } \\
\text { to centers (minutes) }\end{array}$} & \multirow{2}{*}{$\begin{array}{c}\text { Synthetic index } \\
\text { (conventional } \\
\text { minutes) }\end{array}$} \\
\hline & & & & $\begin{array}{l}\text { voivode- } \\
\text { ship }\end{array}$ & $\begin{array}{l}\text { sub- } \\
\text { regional }\end{array}$ & poviat & \\
\hline $\begin{array}{l}\text { Central Pomerania } \\
\text { (Środkowopomorska) }\end{array}$ & 37 & 9 & 352 & 124 & 73 & 23 & 73 \\
\hline Masurian (Mazurska) & 21 & 5 & 126 & 118 & 75 & 27 & 73 \\
\hline $\begin{array}{l}\text { South Podlachia } \\
\text { (Południowopodlaska) }\end{array}$ & 33 & 5 & 176 & 132 & 58 & 25 & 73 \\
\hline $\begin{array}{l}\text { Upper Bug river } \\
\text { neighbourhood } \\
\text { (Pobużańska) }\end{array}$ & 12 & 2 & 88 & 119 & 65 & 31 & 72 \\
\hline Carpathian (Karpacka) & 50 & 7 & 503 & 70 & 44 & 19 & 44 \\
\hline Sudetic (Sudecka) & 25 & 3 & 235 & 113 & 52 & 24 & 64 \\
\hline Total & 178 & 30 & 1,481 & 139 & 53 & 26 & 74 \\
\hline Share of Poland & 7.2 & 9.5 & 3.8 & & & & \\
\hline
\end{tabular}


In communes located there, values for the synthetic index of peripherality usually exceed 70 minutes. The peripheral areas in question are as follows: 1 - Central Pomeranian (Środkowopomorska), 2 - Masurian (Mazurska), 3 - South Podlachia (Południowopodlaska), 4 - Upper Bug river neighbourhood (Pobużańska), 5 - Carpathian (Karpacka), 6 - Sudetic (Sudecka). Together, these areas cover around $10 \%$ of Poland, with some $4 \%$ of the country's population. The largest peripheral area

\section{References}

Geurs K.T., Ritsema van Eck J.R., 2001. Accessibility measures: Review and applications. Evaluation of accessibility impacts of land use transport scenarios, and related social and economic impacts. RIVM Report 408505 006, Bilthoven: National Institute of Public Health and the Environment, http://rivm.openrepository.com/rivm/ bitstream/10029/9487/1/408505006.pdf [09.08.2016].

Geurs K.T., van Wee B., 2013. Accessibility: perspectives, measures and applications [in:] B. van Wee, J.A. Annema, D. Banister (eds.), The Transport System and Transport Policy: An Introduction, Cheltenham-Northampton: Edward Elgar, pp. 207-226.

KARLQVIST A., 1975. Some theoretical aspects of accessibility-based location models [in:] A. Karlqvist, L. Lundqvist, F. Snickars (eds.), Dynamic allocation of urban space, Lexington: DC Health.

KomornickI T., ŚleszrńsKI P., Rosik P., POMIANOWSkI W., StępNiak M., SiŁKa P., 2010. Dostępność przestrzenna jako przesłanka kształtowania polskiej polityki transportowej. Biuletyn KPZK PAN, 241.

LitMAN T., 2014. Evaluating accessibility for transportation planning: Measuring People's Ability To Reach Desired Goods and Activities. is Central Pomerania, comprising 37 communes with some 352,000 inhabitants. The peripheral region that is most heavily populated is in turn Carpathian (region comprising 51 communes with 503,000 people).

Editors' note:

Unless otherwise stated, the sources of tables and figures are the authors', on the basis of their own research.
Victoria (CA): Victoria Transport Policy Institute, http://www.vtpi.org/access.pdf [09.08.2016].

Mazur M., Bański J., CZapleWski K., Śleszrński P., 2015. Wiejskie obszary funkcjonalne - próba metodyczna wyznaczenia ich obszarów i granic. Studia Obszarów Wiejskich, 37, pp. 7-36.

ŚLESZYŃSKI P., 2012. A geomorphometric analysis of Poland on the basis of SRTM-3 data. Geographia Polonica, vol. 85, no. 4, pp. 47-61.

ŚLESZYŃSKI P., 2014a. Dostępność czasowa i jej zastosowania. Przegląd Geograficzny, vol. 86, no. 2, pp. 171-215.

ŚLESZYŃSKI P., 2014b. Transport- and settlement-related time temporary efficiency of road journeys taken in Poland. Geographia Polonica, vol. 87, no. 1, pp. 157-160.

ŚLESZYŃSKI P., 2014c. Distribution of population density in Polish towns and cities. Geographia Polonica, vol. 87, no. 1, pp. 61-75.

ŚLESZYŃSKI P., 2014d. Zmiany dostępności czasowo-przestrzennej w wyniku inwestycji drogowych finansowanych ze środków Unii Europejskiej (2004-2012). Czasopismo Geograficzne, vol. 85, nos. 1-2, p. 7-27.

ŚLESZYŃSKI P., 2015. Expected traffic speed in Poland using Corine land cover, SRTM-3 and detailed population places data. Journal of Maps, vol. 11, no. 2, pp. 245-254. 


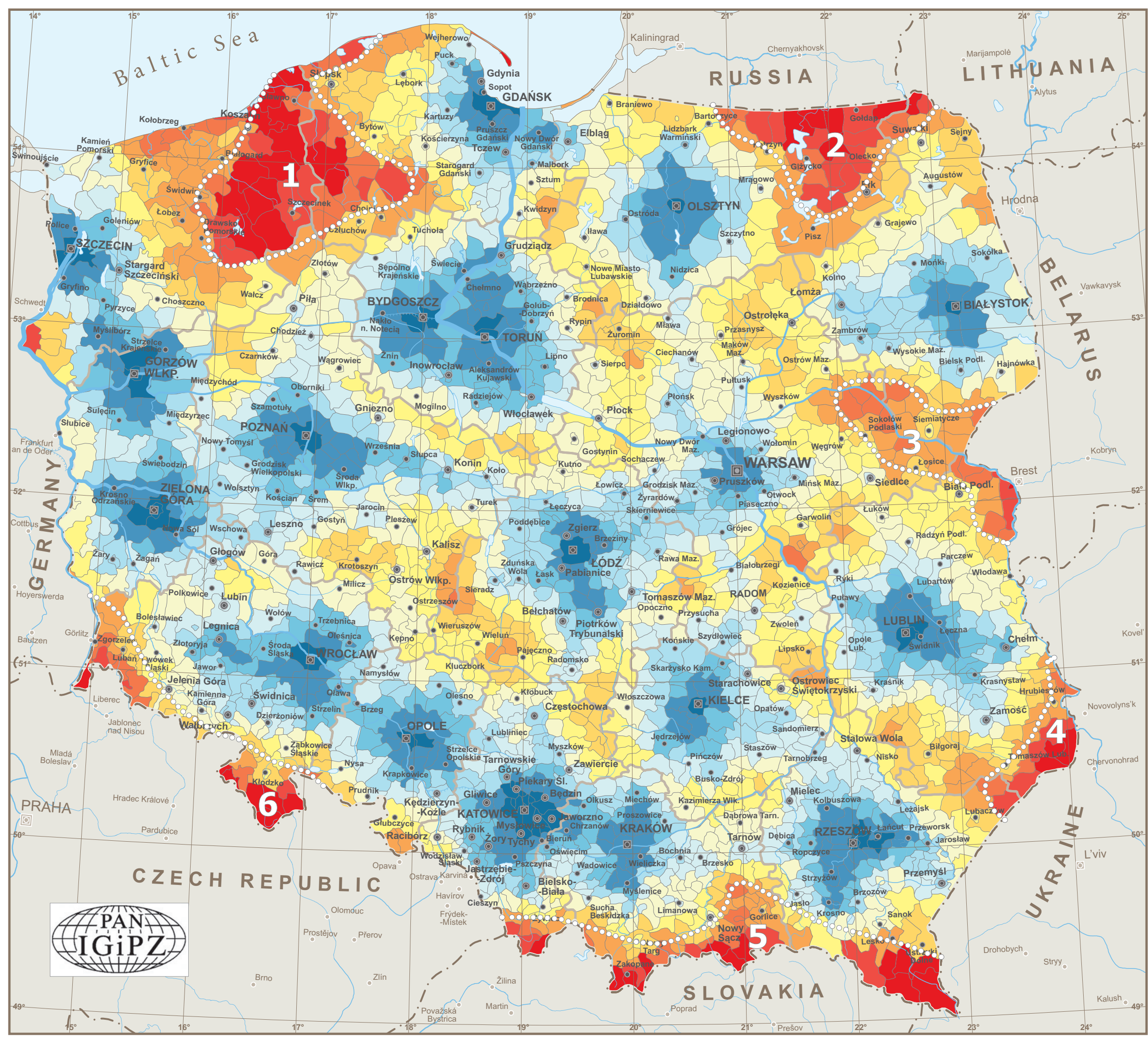

A SYNTHETIC INDEX OF THE SPATIO-TEMPORAL ACCESSIBILITY OF COMMUNES IN POLAND Przemysław Śleszyński

Scale 1:3,000,000 $25 \quad 50 \quad 75 \quad 100 \mathrm{~km}$

$\begin{array}{llllllllllll}7 & 20 & 30 & 35 & 40 & 45 & 50 & 55 & 60 & 65 & 70 & 75\end{array}$

Capital categories:
回 Poland
【 voivodeship
๑ subregional
- poviat

0000 Designations of peripheral areas:

- subregional 2- Masurian (Mazurska)

- povia 4- Upper Bug river neighbourhood (Pobuziansksa) 5 - Carpathian (Karpacka)
6 - Sudetic (Sudecka)

Peripheries delimitation

$W_{1}=0.37 t_{w}+0.25 t_{s}+0.38 t_{p^{\prime}}$, where

- average time accessibility from commune to voivodeship center - average time accessibility from commune to subregional center accessibility from commune to poviat center $0.37,0.25$ and 0.38 in formula represented share of population

\begin{tabular}{|c|c|c|c|c|c|c|c|}
\hline \multirow{2}{*}{$\begin{array}{l}\text { Peripheral areas } \\
\text { (original in Polish) }\end{array}$} & \multirow{2}{*}{$\begin{array}{l}\text { Number } \\
\text { of com- } \\
\text { munes }\end{array}$} & \multirow{2}{*}{$\begin{array}{l}\text { Area } \\
\left(\mathrm{km}^{2}\right)\end{array}$} & \multirow{2}{*}{$\begin{array}{c}\text { Number } \\
\text { of popula- } \\
\text { titon.) } \\
\text { (thous.) }\end{array}$} & \multicolumn{3}{|c|}{$\begin{array}{l}\text { Average time accessibility } \\
\text { to centers (minutes) }\end{array}$} & \multirow{2}{*}{$\begin{array}{l}\text { Synthetic } \\
\text { index } \\
\text { (conven- } \\
\text { tional } \\
\text { minutes) }\end{array}$} \\
\hline & & & & $\begin{array}{c}\text { voivode- } \\
\text { ship }\end{array}$ & $\begin{array}{l}\text { subre- } \\
\text { gional }\end{array}$ & poviat & \\
\hline \begin{tabular}{|l|} 
Central Pomeranian \\
(SSrodkowopomorska)
\end{tabular} & 37 & 9,035 & 352.4 & 124 & 73 & 23 & 73 \\
\hline \begin{tabular}{|l}
$\begin{array}{l}\text { Masurian } \\
\text { (Mazurska) }\end{array}$ \\
\end{tabular} & 21 & 4,594 & 126.1 & 118 & 75 & 27 & 73 \\
\hline \begin{tabular}{|l} 
South Poollachia \\
(Potudniowopodlaska)
\end{tabular} & 33 & 4,671 & 175.9 & 132 & 58 & 25 & 73 \\
\hline $\begin{array}{l}\text { Upper Bug river } \\
\text { neiehbourhood } \\
\text { (Pobuzuanska) }\end{array}$ & 12 & 1,986 & 88.2 & 119 & 65 & 31 & 72 \\
\hline \begin{tabular}{|l} 
Carpathian \\
(Karpacka)
\end{tabular} & 50 & 6,687 & 503.4 & 70 & 44 & 19 & 44 \\
\hline \begin{tabular}{|l} 
Sudetic \\
(Sudecka)
\end{tabular} & 25 & 2,679 & 234.6 & 113 & 52 & 24 & 64 \\
\hline \begin{tabular}{|l|l} 
Total \\
\end{tabular} & 178 & 29,652 & \begin{tabular}{|l|l|}
$1,480.5$ \\
\end{tabular} & 139 & 53 & 26 & 74 \\
\hline
\end{tabular}

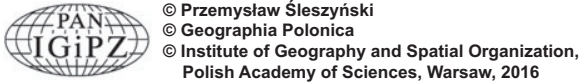

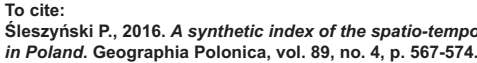




\section{REFEREES AND ADVISERS TO GEOGRAPHIA POLONICA 2016}

The Editors would like to extend their deepest appreciation to all the Reviewers and Advisers for their invaluable help in reviewing the paper submitted to Geographia Polonica

\section{Marco Adelfio \\ OLAF BASTIAN}

Sebastian Bernat

KRZYSZTOF BŁAŻEJCZYK

TeResa BRZEZIŃSKa-Wóscik

GABRIEL BugÁR

PaWet Chrustek

Graham Clarke

Allan Cochrane

DOROTA DOBROWOLSKA

BOLEStAW DOMAŃSKI

Karen EISENHART

Matgorzata Falarz

Adela García-Aracil

Grzegorz Gorzelak

Elena A. Grigorieva

Mirostaw GrochowskI

Aakriti Grover

KRZYSZTOF GWOSDZ

TIM HaLL

Bert Helmsing

JURA HREŠKo

Martin Hermy

HoRÑÁK MARCEL

JERZY JONCZAK

Peter Jordan

KafKALAS GrigorIS

Veronika Kalusová

Ewa KoŁaczKowska

ArKadiusz Kotoś

Éva KONKOlY-GYURÓ

Piotr Korcelli

Adam Kotarba

JACEK KOZAK

ROBERT KRZYSZTOFIK
Chalmers University of Technology, Gothenburg, Sweden

Leibniz Institute of Ecological Urban and Regional Development (IOER) in Dresden, Germany

Maria Curie-Skłodowska University (UMCS) in Lublin, Poland University of Warsaw, Poland

Maria Curie Skłodowska University, Lublin, Poland

University of Constantinus the Philosopher in Nitra, Slovakia

Anna Pasek Foundation, Będzin, Poland

University of Leeds, United Kingdom

The Open University, United Kingdom

Forest Research Institute, Raszyn, Poland

Jagiellonian University, Kraków, Poland

Edinboro University, United States

Universit of Silesia in Katowice, Poland

Universidad Politécnica de Valencia, Spain

Warsaw University, Poland

Russian Academy of Sciences, Russia

University of Warsaw, Poland

University of Delhi, India

Jagiellonian University, Kraków, Poland

University of Winchester, United Kingdom

Erasmus University Rotterdam, The Netherlands

University of Constantinus the Philosopher in Nitra, Slovakia

University of Leuven, Belgium

Comenius University in Bratislava, Slovakia

Pomeranian University in Słupsk

Austrian Academy of Sciences, Vien, Austria

Aristotle University of Thessaloniki, Greece

Masaryk University, Brno, Czech Republic

Polish Academy of Sciences, Warsaw, Poland

Jagiellonian University, Kraków, Poland

University of West Hungary, Hungary

Polish Academy of Sciences, Warsaw, Poland

Polish Academy of Sciences, Warsaw, Poland

Jagiellonian University, Kraków, Poland

University of Silesia in Katowice, Poland 
VIKTOR KVETON

Francisco S.B. Ladeira

Katja Laute

MiLAN LeHOTSKÝ

ANDRZEJ LISOWSKI

ADAM ŁAJCZAK

Markus Naser

SAKo Musterd

Andrew Newton

Michael NiedzielskI

Martin OuŘedníček

Anssi PaAsI

Petros Petsimeris

Danuta Piróg

Adam PŁoszas

WOJCIECH POMIANOWSK

Olimpiu Pop

OlAF SCHMIDT

Nicolai Sluka

Matgorzata Stawska

MieczrStaW SOBIK

Michael Solem

Ewa Szafrańska

JACEK SZMAŃ́DA

MARCIN ŚWITONIAK

Marcel Torok-OAnCe

Andrzej Traczyk

Václav Treml

TOMASZ Wites

Peter Wood

Michael Woods

CZEStAW WYSOCKI
Charles University in Prague, Czech Republic

University of Campinas, Brazil

Geological Survey of Norway (NGU), Trondheim, Norway

Slovak Academy of Sciences, Bratislava, Slovakia

University of Warsaw, Poland

Pedagogical University in Kraków, Poland

University of Würzburg, Germany

University of Amsterdam, The Netherlands

University of Huddersfield, United Kingdom

University of North Dakota, United States

Charles University in Prague, Czech Republic

University of Oulu, Finland

Université Paris 1 - Panthéon-Sorbonne, France

Pedagogical University in Kraków, Poland

University of Warsaw, Poland

Polish Academy of Science, Warsaw, Poland

Babes-Bolyai University, Romania

University College Dublin, Ireland

Moscow State University, Russia

Warsaw University of Life Sciences - SGGW, Poland

University of Wrocław, Poland

Association of American Geographers, Washington DC, United States

University of Łódź, Poland

Pedagogical University in Kraków, Poland

Nicolaus Copernicus University, Toruń, Poland

West University of Timisoara, Romania

University of Wrocław, Poland

Charles University in Prague, Czech Republic

Warsaw University, Poland

University College London

Aberystwyth University, United Kindgdom

Warsaw University of Life Sciences - SGGW, Poland 